\title{
RAPD based molecular diversity analysis of different Fusarium udum Butler isolates of pigeonpea wilt
}

\author{
AMOL S. SHINDE*, S.R. KALASKAR, A.H. RATHOD, W.A. SHEIKH AND S. ACHARYA \\ Centre of Excellence for Research on Pulses, Sardarkrushinagar Dantiwada Agricultural University, \\ SARDARKRUSHINAGAR (GUJARAT) INDIA
}

\section{ARITCLE INFO \\ Received : 10.10 .2014 \\ Revised : 01.02 .2015 \\ Accepted : 17.02 .2015}

KEY WORDS :

RAPD, Butler, PCR, Primer, Molecular marker, Pigeonpea wilt, Molecular diversity

*Corresponding author: Email: amolshinde0110@gmail.com

\begin{abstract}
Genetic diversity in pigeonpea wilt pathogen (Fusarium udum butler) was analyzed using 10 isolates collected from major pulse growing regions of Gujarat. The genomic DNA extracted from each isolate of Fusarium udum was subjected to polymerase chain reaction using 20 random decamer primers from OPC series. Only 10 of the 20 RAPD primers were selected on the basis of polymorphism for pooled analysis. The 10 earmarked RAPD primers selected from OPC series amplified 67 DNA fragments with size ranging from 157 to $2068 \mathrm{bp}$. Out of these, 47 were polymorphic giving 70 per cent polymorphism. The total number of amplified fragments varied from 3 in OPC-8 to 11 in OPC-4. The average polymorphic bands per primer were 4.7 and per cent polymorphism ranged from 40 in OPC-15 to 100 in OPC-5. The PIC value varied from 0.64 in $\mathrm{OPC}-8$ to 0.88 in $\mathrm{OPC}-4$.
\end{abstract}

How to view point the article : Shinde, Amol S., Kalaskar, S.R., Rathod, A.H., Sheikh, W.A. and Acharya, S. (2015). RAPD based molecular diversity analysis of different Fusarium udum Butler isolates of pigeonpea wilt. Internat. J. Plant Protec., 8(1) : 81-85. 